\title{
Use of Career Education and Occupation Information Services in Boosting Enrolment into Vocational and Technical Education Programs in Nigeria
}

\author{
Igbinedion, V. I. ${ }^{1} \&$ I. J. Ojeaga ${ }^{1}$ \\ ${ }^{1}$ Department of Vocational and Technical Education, Faculty of Education, University of Benin, Benin \\ Correspondence: Igbinedion, V. I., Department of Vocational and Technical Education, Faculty of Education \\ University of Benin, Benin City, Edo State, Nigeria. Tel: 229-805-601-4291. E-mail: vicidion@gmail.com
}

Received: May 11, 2012 Accepted: May 31, 2012 Online Published: July 16, 2012

doi:10.5539/ies.v5n4p229 URL: http://dx.doi.org/10.5539/ies.v5n4p229

\begin{abstract}
The major thrust of technical and vocational education (TVE) worldwide is to address issues of youth unemployment, poverty and international competitiveness in skills development towards current and projected opportunities and challenges. The paper posits that despite the evidence of numerous reforms in vocational and technical education programs over the years, they still remain greatly detested by students and parents in Nigeria as evidenced in low enrolment when compared with sciences, engineering, banking and finance, and medicine just to mention but a few. This may be because of lack of understanding of the importance, scope and content of the program or lack of occupational information. Some wrongly view technical and vocational education programs as education for the handicapped or education for those who cannot cope with the sciences and social sciences. This paper therefore, examines the factors responsible for low enrolment into technical and vocational education programs, its implications for Nigeria and suggests how career education and effective occupational information service can help to stem this trend. It is recommended that career education should be used to create the necessary career awareness and occupation information made readily to students to enable them make informed career choices.
\end{abstract}

Keywords: vocational education, technical education, enrolment, career education, occupational information

\section{Introduction}

Education has from inception been recognized as a veritable means of progress for nations and individuals. This is why nations after nations have progressively reviewed their systems of education with a view to bringing about speedy national development as a country's level of socio-economic development is generally linked to the type of educational philosophy and system in operation (Ekpenyong, 2008). Nigerian history has it that as far back as 1921, Phelps-Stokes Commission recommended that education should be adopted to the needs of the people and that objectives should include the development of character, promotion of healthy living and acquisition of industrial and agricultural skills (Toby, 2000). Fafunwa (1974) in the same author made it clear that African reconstruction, rebirth and development can only become a reality if Africa is prepared to place more emphasis on technical and vocational education. Toby further notes that among various disciplines in education, vocational and technical education occupies the most single important position. In a similar vein, McGrath (2005) states that the major thrust of technical and vocational education (TVE) worldwide is to address issues of youth unemployment, poverty and international competitiveness in skills development towards current and projected opportunities and challenges. All these views underscore the scope and importance of technical and vocational education in a nation's development equation.

In spite of its importance, technical and vocational education in Nigeria is so misconstrued that it has become extremely difficult in management perspective, to administer the program to meet societal ever changing needs (Toby, 2000). According to African Economic Outlook (2010), while enrolment in technical and vocational programs is quite high in North Africa (averaging 22.95 per cent of total secondary school enrolment between 2001 and 2005), the vocational education sector generally occupies a much smaller - if not marginal - position in school systems in countries in sub-Saharan Africa (5.2\% between 2001 to 2005 with a falling trend since 2003) compared to the developed countries in the same period (18.6\%) and other developing regions, such as Latin 
America (11.6\%) and South East Asia (9.5\%). According to Abdul-Wahab (2010), in the United Kingdom, 66\% of those in secondary and higher education are in TVE. In France, it is $65 \%$ and Germany $72 \%$. Singapore and South Korea moved to 92 and over 50\%, respectively. In Bahrain, more than 55\% of secondary school students are enrolled in technical colleges. The Middle East has a target of 50\%. The reason, he said, is: "No skilled manpower, no economy. No economy can function without technical and vocational education and that means no way out of poverty." In analyzing the needs of the adolescents, Giles, McCutchen and Zehiel (1942) in Ekpenyong (2008) included the following: (i) Wise use of goods and services (ii) Appropriate vocation (iii) Vocational competence. Hence no nation that wants to properly engage the youth can afford to underrate vocational and technical education.

The story of vocational and technical education in Nigeria is different. According to Nwagwu (2004), presently, the program is bedeviled by many challenges that hinder the realization of its objectives as specified by the National Policy on Education of Federal Government of Nigeria (2004). One of these challenges is low enrolment. It is the concern of this paper that enrolment into technical and vocational programs may be low not because Nigerian youths are lazy nor do not want to use their hands to work. But it may be because many Nigerians do not fully understand the benefits, scope and content of the program and lack of vocational/career education and occupation information services to students while in or out of schools. As noted by Ebomoyi and Iyawe (2006), as secondary school education comes to an end for many students, they are faced with the choice of the course to apply for when preparing to sit for the joint matriculation examinations conducted by the Joint Admissions and Matriculation Board. Many of them make choices without proper understanding of their abilities, interests and attitudes. According to Andah (1991) young people are said to select occupations like medicine, engineering, accounting mainly because of the positions and prestige attached to the job and not necessarily as a result of conscious assessment of the individual's interests and abilities. Therefore, career education may be a veritable means of providing career awareness and information services to students in order to improve enrolment in vocational and technical education in Nigeria. Students, parents and the society at large look unto the school to help the adolescents and youth make career decision based on realistic abilities, interests and availability. This paper therefore, explores the use of career education and occupation information services in boosting enrolment in vocational and technical education programs in Nigeria.

\section{State of Graduate Out-turn and Enrolment into Technical and Vocational Education Programs at Tertiary and Secondary and Vocational Technical Institutions in Nigeria}

It is important to view some trend in graduate out-turn from two types of institutions in Nigeria namely; polytechnics (which is oriented towards the preparation of students for vocational and technical programs) and universities. The trend is presented in table 1.

Table 1. Summary of Enrolment and Graduate Out-Turn in various types of Institution in Nigeria

\begin{tabular}{lllll}
\hline Academic Year & \multicolumn{2}{l}{ Polytechnics (including Monotechnics) } & Universities & \\
Year & Enrol. & Out-turn & Enrol. & Out-turn \\
\hline $1993 / 94$ & 136,749 & 34,635 & 264,584 & 44,925 \\
$1994 / 95$ & 162,887 & 27,889 & 291,861 & 45,309 \\
$1995 / 96$ & 162,148 & 40,806 & 316,260 & 47,271 \\
$1996 / 97$ & 188,760 & 43,657 & 355,844 & 53,941 \\
$1997 / 98$ & 202,686 & 33,887 & 371,083 & 70,891 \\
\hline
\end{tabular}

Source: Ekpenyong (2008)

As seen from table 1 above, at the polytechnic and mototechnics levels, enrolment ranged from 136,000 to 202,000 within the period under review. Out-turn however ranged from 27,000 to 43,000 which is somewhat poor. This suggests a high dropout rate at this level in technical and vocational programs with the mandate for producing middle level manpower. At the university level, enrolment ranged from 264,000 to 371,000 while out-turn for the corresponding period ranged from $44,000-70,000$. The implication of this trend is that there is a heavy shortfall in high level technical personnel produced in the country with attendant implications for socio-economic standing of Nigeria. 
Comparatively, examine enrolment into vocational and technical colleges and secondary schools between 1991 and 2001 hereunder in table 2.

Table 2. Enrolment in Vocational and Technical Institutions and Secondary Schools (1991 - 2001)

\begin{tabular}{lllll}
\hline Year & $\begin{array}{l}\text { Number of } \\
\text { Technical Colleges }\end{array}$ & Student Enrolment & $\begin{array}{l}\text { Number of } \\
\text { Secondary Schools }\end{array}$ & Student Enrolment \\
\hline 1991 & 208 & 46,083 & 3,854 & $1,653,891$ \\
1992 & 202 & 40,878 & 5,840 & $1,814,000$ \\
1993 & 190 & 72,136 & 5,948 & $1,865,189$ \\
1994 & 300 & 72,136 & 6,092 & $2,794,498$ \\
1995 & 240 & 76,434 & 5,991 & $2,934,349$ \\
1996 & 252 & 89,536 & 5,859 & $2,941,781$ \\
1997 & 261 & 1,179 & 6,001 & $2,923,791$ \\
1998 & 261 & 1,426 & 5,860 & $2,901,993$ \\
1999 & 261 & 1,425 & 6,008 & $3,123,277$ \\
2000 & 261 & 1,835 & 6,009 & $3,600,204$ \\
2001 & 261 & 1,835 & 5,959 & $4,032,083$ \\
\hline$S 04 r$ & & &
\end{tabular}

Source: Dike (2009)

The trend in table 2 is very disturbing. Whereas in 1991 to 1996 enrolment trend was on the rise ranging from 40,000 to 89,000, however, from 1997 to 2001, enrolment fell drastically to below 2000. In the case of secondary schools enrolment progressively increased from 1.6 million in 1991 to 4,032,083 in 2001. With this trend of enrolment, one can see very vividly the manpower implication for Nigeria and her quest for national growth and development. This underscores the point this paper is making that there is need to canvass for enrolment into technical and vocational education programs at all levels of the education system in Nigeria. The objectives of technical and vocational education in Nigeria are laudable as enunciated in National Policy of Education (2004) and they include:

- To provide trained manpower in applied science, technology, and commerce particularly at sub-professional levels.

- To provide the technical knowledge and vocational skills necessary for agriculture, industrial, commercial and economic development.

- To provide people who can apply scientific knowledge to the improvement and solution of environmental problems for the convenience of man.

- To give an introduction to professional studies in engineering and other technologies.

- To give training and impart necessary skills leading to the production of craftsman, technician, and other skilled young men and women to have an intelligent understanding of the increasing complexity of technology.

In spite of these laudable objectives, enrolment into technical and vocational education programs seems to be on the downward trend as can be seen in tables 1 and 2. It is therefore imperative to examine some factors responsible for low enrolment into technical and vocational education programs in Nigeria. Some of these factors are discussed hereunder.

\section{Factors responsible for Low Enrolment in Technical and Vocational Education in Nigeria}

Vocational and technical education in Nigeria is bedeviled by the following problems amongst others:

\section{- Poor Societal Perception}

In Nigeria, many people are yet to understand the meaning, scope and content of vocational and technical education. Some view it as education for the handicapped or education for those who cannot cope with the sciences (Osa-Edoh, 2008). According to Gambo (1980), in the same author, there is still a strong tendency 
towards white collar jobs as a result of low status associated with most kind of vocational and technical Education. Most parents want their children to be medical doctors, accountants, lawyers, administrators and good politicians.

\section{- Poor Societal Attitude}

The attitude of people towards vocational and technical education contributes to the problems in teaching the subject. Idialu (2007) notes that in schools, the teacher could be teaching people who are not interested in the subject that is being taught. According to him, the new policy document on education in section 6 , subsection 47 recognizes the general public attitudes which regard technical education as somewhat inferior to other types of education.

\section{- $\quad$ Elitism}

Elitism could be described as the belief of a group in society that because of superior privileges, power and talent they tend to hold on to this belief through a system of education that will sustain this group's interest (Oviawe and Anavberokhai, 2008). Because the elites control the means of decision-making, priority is not accorded vocational and technical education. Many elites will not allow their children offer vocational and technical education, as that would be considered as deviating from the "honorable" path of their profession, and this would be considered as a disgrace to the families.

\section{- Poor Entry Level}

Oviawe and Anavberokhai (2008) also note that students who enroll in vocational and technical education programs are considered to have low aptitude. The technical schools find it hard to attract good students because there is a strong misconception that they are reserved for the never-to- do-wells and other negative by-products. Those admitted because they cannot find other things to do barely pass through the program because of poor aptitude and attitude.

\section{- Lack of Recognition}

There is a low recognition associated with manual labor in Nigeria. Unlike her counterparts in developed countries, the skilled craftsman does not enjoy the same recognition (Oviawe and Anavberokhai, 2008). Our leaders cannot give vocational and technical education the attention it deserves without changing their thinking models' that drive their decisions (Dike, 2009). Changing their mind-set is a critical first step to restructuring the sector because without changing their thinking, values and beliefs, it is impossible to change their wrong impression about the field. As it were, poor thinking leads to poor results.

\section{- Discrimination against Graduates of Technical and Vocational Education}

There is also the problem of unhealthy perception or discrimination against technical graduates (Ogidefa, 2010). It was stated that this discrimination is virtually visible amongst graduates of technical schools (technical college, monotechnics, colleges of technology, polytechnics) and university graduates. Up till now, the former is being managed by National Board for Technical Education while the latter is under the supervision of National Universities Commission.

\section{Career Education option as a Boost for Enrolment}

Career refers to a pattern of decision, transactions and adjustments related to one's role in work, education, family, community and leisure (Iwuama, 1991). On other hand, career education is also seen as providing the students with the skills, attitude and information which they need to successfully enter the labor market smoothly at whatever point they leave school. Ekpenyong (2008) noted that Frank Parson (1909) in his book "choosing a vocation” lists 3 factors which should govern career guidance inter alia: (1) a clear understanding of oneself; it's attitudes, abilities, interests, ambitions, resources, limitations and causes (2) a knowledge of the requirements and conditions of success, advantages and disadvantages, compensations, opportunities and the prospects in different lines of work; and (3) true reasoning of the relations of the two groups of factors. This implies that individuals should make a choice by true understanding of number 1 and 2 above for appropriate career development. Akinboye (2002) corroborated this fact by stating that the responsibility of school career counselor or master is to help the students to develop healthy attitudes, knowledge, skills and behavior towards work so that they can make effective and hitch-free transitions from school to work.

\section{Objectives of Careers Education in Creating Career Awareness amongst Youth}

According to Iwuama (1991), objectives of vocational guidance/career education include: 
- $\quad$ To increase students' understanding of their abilities, interests, values, and other personality traits distinct from those of others and to use the understanding to identify occupational areas which may be more appropriate for them.

- $\quad$ To aid students develop an acceptable self-image and realistic attitude to school achievement as necessary prelude to vocations.

- To help the students to understand the prevailing circumstances in the world of work and the worthwhileness of legitimate occupations as well as inculcating in them the dignity of labor.

- $\quad$ To help them identify different occupational areas that are available both in the immediate and more distant future, the nature and purpose of each and the direction to which each leads.

- $\quad$ To assist students develop and execute career plans which will help them in achieving their career goals by taking appropriate courses at the secondary level or other relevant steps/training after the secondary level that would qualify them for particular occupations.

\section{Need for Occupational Information Services for Students and Youth}

Occupational information is the valid and usable data about positions, jobs and occupations, including duties, requirements for entrance, conditions of work, rewards offered, advancement pattern, existing and predicted supply of and demand for workers, and sources for further information (Norris, 1974) in Andah (1991). In the same vein, Ikeotuonye (1983) noted that occupational information is a process which incorporates as many details as possible about the available occupational opportunities meant to help the individual not only to make an effective career choice but also to adjust to and make success in it. According to Osa-Edoh (2008), under a good vocational guidance/careers education, students can be made to understand how beneficial it is to set one's aspiration in accordance with individual abilities and interests. She further notes that a good school program of careers education is of value to the teachers who can be equipped with the necessary skills on how to collect, analyze interpret and present relevant information about occupations to students. Ekpenyong (2008) notes that based on the government national policy, vocational guidance or career education should benefit vocational and technical institutions in at least two ways: (1) by the provision of careers guidance and counseling service (b) through job placement.

\section{Ways of using Career Awareness for Boosting Enrolment into Vocational and Technical Education Programs}

Proper career awareness may help to boost enrolment in vocational and technical education in Nigeria. The career educator/master can help to create awareness in the following ways:

\section{- Careers Convention/Conference}

This is a large official meeting, usually lasting for a few days, at which people with the same work or interests come together to discuss their views (Oxford Advanced Learner's Dictionary (2001). It is usually a discussion or group which gives opportunity to experts and professionals to talk about careers. Through career conventions or conferences, students have the opportunity to ask questions about a vocation. At such meetings, the professionals from vocational and technical education could highlight on their occupations with regard to what they do, the advantages and disadvantages, methods of entry, salaries, promotions (Iwuama, 1991). A career conference could be organized for the whole school, a class, or for a group of schools and could be for a single day or several days or weeks. It could be organized for final year students on the verge of leaving school or for junior or senior secondary phase of their schooling.

\section{- $\quad$ Field Trips or Work Visits}

Field trips could help to provide career information to students. In undertaking a field for career awareness, students are organized to visit experts and professionals in their working places to learn about their jobs. In this case, students can visit professionals and experts in the field of vocational and technical education to learn how they work, what they do and qualifications for entry into the field. Field trips or work visits are a way to reinforce and expand on concepts taught in class (Kelly, 2011).

\section{- Industrial Training/Experience}

This is a career education technique in which students are mandated to work. Industrial Experience exposes students to the world of work and enables them to appreciate real-life problems facing industries (Covenant University, 2011). The period of industrial training ranges from 4 months to 1 year depending on the higher institution or course of study. During this experience, they are exposed to actual work situation especially office management and their interest could be stimulated in the field of vocational and technical education. 


\section{- Audio-Visual Aids}

This involves the use of both sound and pictures to explain learning concepts. It involves the use of aids such as films, tapes, slides, television and radio etc. in the case of vocational and technical education, the different areas of specialization such as office technology, industrial technology, accounting and home economics could be demonstrated to the students through the use of audio-visual aids and this may stimulate their interest in the field.

\section{- Career Information Center}

A career information center in the school serves as a collection center for various educational and vocational information which could help the students in their vocational plans (Iwuama, 1991). In such a center, newspaper cuttings on careers/vocations, occupational pamphlets, reference books, files with vocational/educational information, college/polytechnics/university brochure are conspicuously displayed for teachers, parents and students to benefit from. Students, teachers and parents should be encouraged to visit the career information center regularly to get abreast with the current information and happening in the world of education and work within the locality and beyond.

\section{- Career Games}

Career games, role playing career fictions etc. containing account portrayed through the experiences of one or more fictional characters of vocational and technical education occupation which may encompass duties, qualifications, preparations, conditions, nature of work and advancement, serve as important career information media about the numerous benefits of the program (Andah, 1991).

\section{- Simulation}

Computer simulation is the discipline of designing a model of an actual or theoretical physical system, executing the model on a digital computer, and analyzing the execution output (Fishwick, 1995). Simulation embodies the principle of 'learning by doing' and serves to drive synthetic environments and virtual worlds. When vocational education occupations are simulated, the students can learn about it and may develop interest in it.

\section{Conclusion}

This paper has viewed career education development and occupational information with regard to addressing the low enrolment syndrome in technical and vocational programs in Nigeria. It examined some factors influencing career choice among adolescents and traced the problems of low enrolment into technical and vocational education programs to some social factors and suggested some practical ways through adequate career awareness and occupational information services in which these problems could be addressed for the benefit of the country socio-economic advancement and political stability.

\section{Recommendations}

- Career information should be provided to the students through talk shows; seminars, orientations, career weeks, role playing, simulations and television programs especially, at junior secondary and senior secondary school levels.

- Vocational and technical education should be made more relevant to the needs of the individual and society.

- $\quad$ Parents should allow their children to make career choices personally and not coerce them into their own career interests.

\section{References}

Abdul-Wahab, H. (2010). Reported by Olatunji, B. Nigeria: 'No Economy Can Function Without Technical, Vocational Education. ThisDay Newspaper. Retrieved from http://www.allafrica.com/stories/201003030484.html (October 1, 2012)

African Economic Outlook. (2010). Access to technical and vocational education in Africa. Retrieved from http://www.africaneconomicoutlook.org/en/in-depth/developing-technical-and-vocational-skills-in-africa-2 008/ (December 2, 2010)

Akinboye, J. O. (2002). Expanding professional and scientific issues in counseling psychology. Lead paper presented at the $21^{\text {st }}$ National Annual Conference of Counseling Association of Nigeria. Benin city

Andah, A. W. (1991). Vocational Development and Occupational Information: An Overview in Unachukwu G.C. and Igborgbor, G.C. Guidance and counseling: A realistic approach. International Universities Press, Owerri. 
Baumgartner, J. (2001). Team Role Play. Retrieved from http://www.jpb.com/creative/index.htm.(December 2, 2010)

Dike, V. E. (2009). Addressing youth employment and poverty in Nigeria: A call for action, not rhetoric. Journal of Sustainable Development in Africa, 2(3), 129-151. Retrieved from www.nigeriavillagesquare.com/...dike/youth-unemployment-and-poverty-in-nigeria-a-call-for-action-not-rh etoric.html (December 2, 2010)

Ebomoyi, M. I., \& Iyawe, V.I. (2006). Career Choice: The persistent rush for a career in medicine. African Journal of Studies in Education, 2(1), 186-94.

Ekpenyong, L. E. (2008). Foundations of Technical and Vocational Education: Evolution and Practice. Supreme Ideal Publishers International Ltd., Benin City.

Fafunwa, A. B. (1974). History of Education in Nigeria London. George Allen and Unwin Ltd.

Federal Republic of Nigeria (2004). National Policy on Education. Lagos. Government Printers.

Fishwick, P. (1995). What is simulation? Retrieved from http://www.google.com.ng/\#hl=en\&sclient=psy-ab\&q=Paul+Fishwick.Thu+Oct+19+10:30\%3A41+EDT+1 995.+WHAT+IS+SIMULATION\%3F*+\&oq=Paul+Fishwick.Thu+Oct+19+10:30\%3A41+EDT+1995.+W HAT+IS+SIMULATION\%3F*+\&aq=f\&aqi=\&aql=\&gs_l=serp.3...4165.4165.0.4680.1.1.0.0.0.0.265.265.2 1.1.0...0.0.HFeV0c2mStU\&pbx=1\&bav=on.2,or.r_gc.r_pw.r_qf.,cf.osb\&fp=1cc30b4dc8d5f58d\&biw $=1093 \&$ bih $=453$. (December 2, 2010)

Idialu, E. E. (2007). Quality assurance in the teaching and examination of Vocational and Technical Education in Nigeria. College Student Journal, 41(3). 649-56. Retrieved from http://findarticles.com/p/articles/mi_m0FCR/is_3_41/ai_n27391160/pg_3/?tag=content;col1 (October 7, 2010)

Ikeotuonye, A. I. (1984). Guidance for Schools: An Introduction. M.I.S. Press Limited, Zaria.

Iwuama, B. C. (1991). Foundations of Guidance and Counseling. Supreme Ideal Publishers Int. Ltd. Benin City

Kelly, M. (2011). Field Trips. Creating Effective Field Trips. About.com Guide. Retrieved from http://712educators.about.com/b/2011/03/16/creating-effective-field-trips.htm. (December 2, 2010)

McGrath, S. (2005). Key issues and challenges for transformation in Phuthi, N. and Maphosa, N. Transforming Higher Education for Effective Technical and Vocational Skills Delivery in Zimbabwe. UNESCO Forum on Higher Education, Research and Knowledge. Retrieved from http://portal.unesco.org/education/en/files/ 52560/11725005455Phuthi. pdf/Phuthi.pdf (October 1, 2010)

Nwagwu, J. U. (2004). Alleviating poverty through vocational education: The Nigerian experience. Faculty of Education, Imo State University, Owerri. Retrieved from http://www.gla.ac.uk/centers/cradall/docs/Botswana-papers/NWAGWUpaper_61.pdf.(December 2, 2010)

Obahiagbon, R. (2007). Counseling on factors to consider when choosing a career. Counseling Association of Nigeria Newsletter. 2(ed.). Ambik Press, Benin City.

Ogidefa, I. (2010). Enhancing Technical Vocational Education in Nigerian Schools. Socyberty. Retrieved from http://socyberty.com/education/enhancing-technical-vocational-education-in-nigerian-schools/4/(October 1, 2010)

Osa-Edoh G. I. (2008). The place of vocational and technical education in skills acquisition by secondary school students - Implication for counseling. Technical and Vocational Education Journal. 1(2). 84-90.

Osa-Edoh, G. I. (2008). The place of vocational and technical education in skills acquisition by secondary school students - Implication for counseling. Technical and Vocational Education Journal, 1(2). 84-90.

Oviawe, J.I. \& Anavberokhai, M.O. (2008). The role of entrepreneurship education in the realization of the National Economic Empowerment and Development Strategy (NEEDS). Technical and Vocational Education Journal, 1(1).

Oxford Advanced Learner’s Dictionary. (2001). Special price edition. Oxford University Press.

Parsons, F. (1909). Choosing a vocation. Boston: Houghton Mifflin.

Saskatoon Public Schools. (2004). Instructional Strategy Online. What is Role Playing? Retrieved from http://www.google.com.ng/\#hl=en\&sclient=psy-ab\&q=Saskatoon+Public+Schools++(2004).+Instructiona+ Strategy+Online.+What+is+Role+Playing\%3F*\&oq=Saskatoon+Public+Schools++(2004).+Instructional+ 
Strategy+Online.+What+is+Role+Playing\%3F*\&aq=f\&aqi=\&aql=\&gs_l=serp.3...3853.3853.0.4649.1.1.0. 0.0.0.593.593.5-1.1.0...0.0.tntb5k2WTI4\&pbx=1\&bav=on.2,or.r_gc.r_pw.r_qf.,cf.osb\&fp=1cc30b4dc8d5f5 8d\&biw=1093\&bih=453. (December 2, 2011)

Shertzar, B., \& Stone, S. (1976). Fundamentals of Guidance. Houghton Mifflin Company, Boston.

Toby, U. T. (2000). Essentials of Management and Leadership in Vocational and Technical Education (2nd Ed). Nigerian Association of Technology Teachers (NATT). Jos. 